\title{
22
}

\section{The outreach programme at Sewanee, University of the South, USA}

\author{
Felix M. Bivens
}

\section{Context}

The Outreach and Community Service programme at the University of the 1 South in Sewanee, Tennessee, was created in 1989. It was part of a wave of many such programmes started by US universities and colleges in the late 1980s and early 1990s, bolstered by Boyer's Scholarship Reconsidered report for the Carnegie Foundation for the Advancement of Teaching (1990). The University of the South, more commonly referred to as Sewanee, is a small (1,500 students), private liberalarts college owned by the twenty-six southern dioceses of the Episcopal Church. It is situated in a remote mountainous location called the Cumberland Plateau, long economically depressed due to its isolation and now-shuttered coal-mining industry. The university has frequently been perceived by local communities as an island of wealth among general hardship and the town-gown relationship has been historically strained. The programme was created in an attempt to improve ties to the community. Further, proponents of the programme also saw it as a structural mechanism for encouraging the institution's generally privileged and affluent students to be more engaged with serious real-world problems.

At the outset, the programme was envisioned simply as a mechanism for students to carry out community service projects. There were no ties to the academic dimension of the university and thus no potential for credited service learning. Nor was there any significant CBR being conducted by the university at the time, particularly as the school was teaching intensive rather than research focused and it prided itself on traditional curriculum and pedagogy. This particular institutional environment forced the outreach programme to function at the margins of the university for many years, although those within the programme saw the potential and need for bringing outreach into closer proximity with academic functions. Over a period of approximately fifteen years, however, outreach was able to shift its positionality within the institution. High levels of student demand, consistent programmatic leadership and changing demographics within the faculty and the university management eventually enabled the outreach programme to make inroads with faculty, which subsequently spawned innovative teaching and research collaborations. 


\section{Organization/structure}

During its first fifteen years of activity, the outreach programme's fell into two primary categories. First, the primary thrust of the programme's local engagement was housing issues. Substandard housing conditions were visible on and around the campus. The outreach office led renovation projects on deteriorated homes and subsequently switched to building entire houses. Second, the office also coordinated a substantial set of international projects. These consisted of alternative spring break (ASB) trips which enabled Sewanee students to travel to several developing countries to take part in two-week service projects. Although the ASB programmes were not connected to the curriculum in any way, the outreach staff often solicited members of the faculty to help co-facilitate these trips. After having been exposed to outreach methods through these ASB experiences, several faculty members began to explore the possibility of piggybacking new academic courses onto existing outreach trips and using the ASBs as infrastructure for field study projects. Similarly, other faculty were becoming more interested in finding ways to engage with poverty and other issues evident in communities near the university. However, these faculty members had minimal connections in the communities outside of the university and had to turn to the outreach staff in order to gain access to - and credibility with - local groups and individuals. Thus the social capital and networks that outreach staff had developed in its first years of work proved invaluable in fostering the creation of new teaching and research endeavours when Sewanee's faculty were finally in a position to institutionally take such ideas forward.

\section{Activities}

Since 2003, the outreach programme has been pivotal in enabling a series of new courses which include action learning and CBR, as follows:

\section{Summer-in-South-Asia programme}

This is a combination of economics courses which focus on the microfinance institutions of the Grameen Bank and the Bangladesh Rural Advancement Committee (BRAC) and include a field study period with rural communities in Bangladesh. A member of the Sewanee economics faculty had close ties with Grameen Bank founder Muhammad Yunus and thus was an early proponent of this model. Working along with the outreach director to gain access to local community organizations, they attempted to develop a Grameen replication in one of the poorest plateau communities in the late 1990s. Although the project failed to get off the ground, a strong relationship was forged. Several years later, the economics professor wanted to create the university's first service learning course, one that would include fieldwork with microfinance institutions in Bangladesh. The outreach office was able to bring this idea to fruition by supporting the endeavour financially and also by seconding a member of the outreach staff to work with the professor, helping coordinate and co-facilitate the course on the ground in 
Bangladesh. The programme has now run for several years consecutively.

\section{Documentary photography}

In 2005, the outreach programme started a new ASB trip to Haiti. There was strong faculty interest to connect with the new programme to build an academic course around the visit to Haiti. One faculty member was a professor of Fine Arts with a specialization in photography. He had previously accompanied outreach ASB programmes and so had a strong sense of how he could work with the outreach staff to mould an academic course around spring break. He created a new course on documentary photography which would utilize the spring break visit to Haiti as the core fieldwork for the course. Pedagogically, the course was a huge shift for this particular professor. Compared to other photography courses he taught, this one become far more interdisciplinary and focused on issues of ethics and power. Rather than adhering to a paradigm of personal creativity, the course focused on the potential role of art to document complex problems in society and to precipitate social change through challenging perceptions and by influencing policy debates.

\section{Human health in the environment}

This course in the university's biology department acts as a sister course to the documentary photography class; it is also structured around the Haiti ASB programme. The course also incorporates local outreach connections, linking pairs of students with families in local communities. The students make weekly visits to community partners to learn about lifestyles and living conditions in the areas beyond the university campus. The primary objectives of the course include:

- build a relationship with, learn from and assist a community family;

- experience life with residents of our larger community and the issues they face;

- apply concepts learned in class to analyze the systemic societal factors that contribute to these local issues in a final written 'documentary'. (McGrath, 2007, p. 1)

The fieldwork in Haiti also engages students with Haitian families to look at similar issues of how the environment impacts health and lifestyles, creating a broad exposure from which students can make connections from literature and comparisons across two extremely challenging settings. The Haiti ASB programme for March 2010 still went forward even after that year's cataclysmic earthquake.

\section{Politics of poverty}

This course within the political science department enabled students to research the systemic causes and impacts of poverty in the communities around the university. Twenty-five percent of the course's assessment turned on a CBR project where students worked with a local agency or group to deepen their knowledge about local poverty issues and to make a contribution to the knowledgebase of 
the organization by short-term research projects and assessments. The outreach office played a key role in brokering the connections between teams of students and community organizations.

\section{Medical ethics}

This course within the philosophy department draws students from a variety of disciplines, including philosophy, biology, pre-medical and anthropology, as it explores the complexities of end-of-life issues. Students engage with local community members through a series of workshops where issues such as euthanasia, brain death and right-to-die laws are discussed. Information about the views of rural communities is collected and the underlying values systems are explored. Students also assist community participants in filling out living will documents and related video statements in which participants provide guidance to their loved ones of how they would like personal, financial and legal issues to be handled. The professor who created and facilitated this course says that it only began to work well when he entered the community through the connections made by the outreach staff, which helped him to reach organizations and community groups with interests in these particular areas, many of which had little previous knowledge.

\section{Introduction to anthropology}

In a manner similar to the previous two courses, the outreach programme facilitated connections between freshman anthropology students and community members. Students were encouraged to get out into nearby mountain communities and take part in local programmes and activities. Less focused on community problems, the course emphasized the unique cultural landscape of the Cumberland Plateau and helped students to understand and appreciate the historical and geographical influences which shape life in those communities.

\section{Civil rights, music and social change}

This summer programme was spearheaded by outreach staff members wanting to create a peripatetic course which studied the American civil rights movement, with actual travel to many important sites from the history of the movement and encountering people who had taken part in the struggle directly. The three-week course took students all over Alabama, Mississippi, Louisiana and finally up the Mississippi River to Chicago. Academically, the course looked at the intersection of politics and culture by bringing together a professor of history and a professor of music who travelled with students and took part in place-based learning alongside their students.

\section{Community-engagement minor}

Sewanee students are in the process creating a new academic minor in community engagement. They have gained the support of the outreach staff and faculty in several departments who advised them in the design of the minor's curricula which the students submitted to the Sewanee academic dean in 2010. 